\title{
HRAS Gene
}

National Cancer Institute

\section{Source}

National Cancer Institute. HRAS Gene. NCI Thesaurus. Code C17060.

This gene plays a role in signal transduction and cellular communication. 